\title{
醅 造研究
}

炤和 24 年 度

\section{清酒醪醱酵炭酸ガスの一利用法}

On the manufacture of sodium-bicarbonate from soda, utilizing $\mathrm{CO}$ gas produced in cource of saké-brewing.

（昭赫二十四年四月十日受理）

$$
\text { 山田正一, 森孝 三, 中野得藏 }
$$

Masakazu Yamada, Kozo Mori and Tokuzo Nakiano

アルコール醴酵中生成する炭酸ガス量法アルコール量と略々等量であるのはGay-Lussac の式により明かて

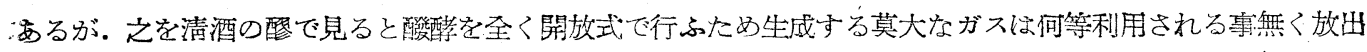
されてアふ。其の量は例へば本年度の酒造米 4.0 餘萬石 (玄米) を本均 1 舦 6 分前後の精白を行ひ全部粎 30

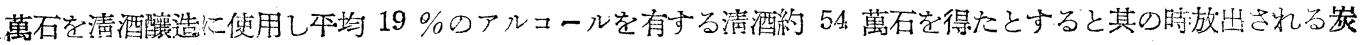
酸ガスは約 15000 瓦前後となる。ただ清酒釂造に於ては其の製造方式が家內工業式小規模のためビールやアル

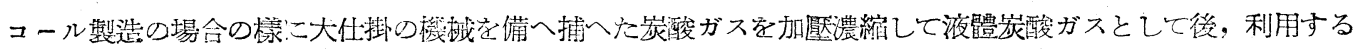

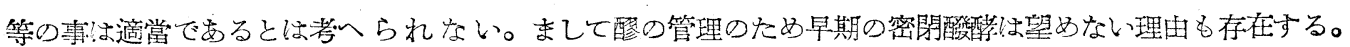

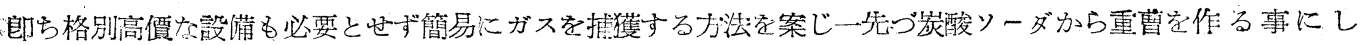

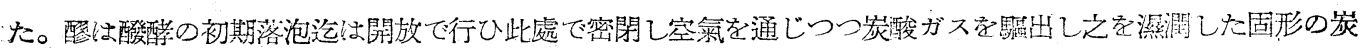

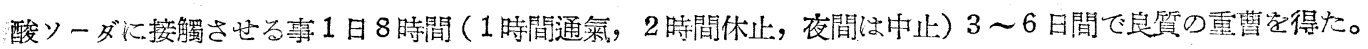

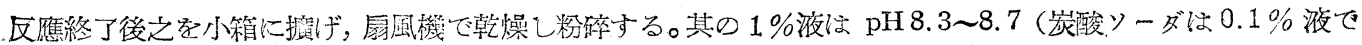
9.60 重曹の市販品は 9.0 のものがあり，局方品は 8.1 8.5) で更に $\mathrm{pH}$ を下げる工夫は必要とならら。又 元來炭酸ソーダは重曹から作るものであるから此の方法怯逆となる譯で將來はアムモニア・ソーダ法化より食

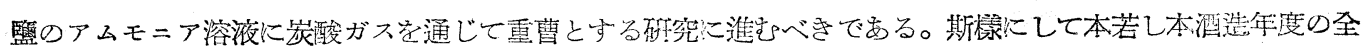
酒につき其の炭酸ガスの 2 割索利用すれば 600 继の重曹が出來る筈である。

實驗

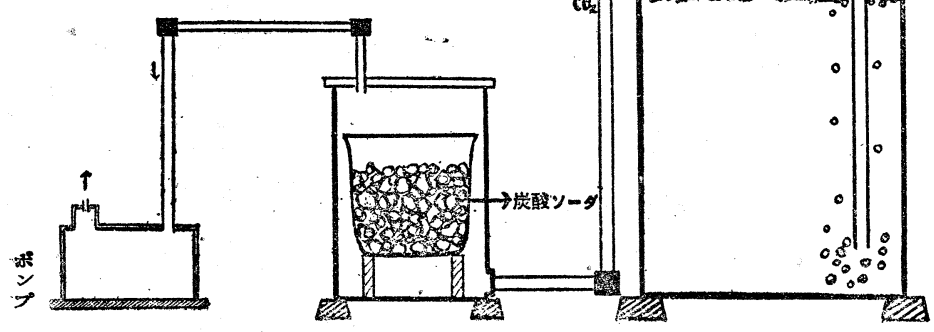

試驗も万み 昭和 23 年度 1 及 び 6 號, 總米 6 石, 11 水，炭酸》 ーダ（南販工鄴用）

第1国自仕远第1 1 路に $10 \mathrm{~kg}$ 製品 $4.16 \mathrm{~kg}$ 本玸 $\mathrm{pH} 8.36$ 第2国目仕达第 6 號沱 $20 \mathrm{~kg}$

製品 $14.14 \mathrm{~kg}$ 平均 $\mathrm{pH} 8.73$ 計ソーダ $30 \mathrm{~kg}$ から $18.3 \mathrm{~kg}$ 通氣を始的た時淿，

第 1 淲 15 日目 品溫 15.5 。 ボーメ3.0アルコール13\% 酸 $0.118 \%$ 
第 6 跨 17 日目

品

終了し范時は，

節1 跟 19 日月

第6 6 榩 27 日目

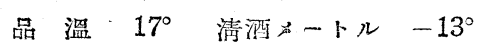

品溫 $15.5^{\circ} \quad \prime+6^{\circ}$

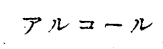

$16.8 \%$

$19.5 \%$

酸 $0.1475 \%$

II $0.1593 \%$

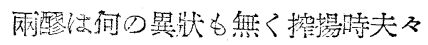
1. 29 日目
清眮メートル
6. 30 日目
$+5.0$
$+10.0$

を示した。

又空氣を通ずるため奥空ポンプより出る廢氮を $200 \mathrm{cc}$ の水に 1 時間通じた時其の中のアルコールに2\%を 示した。因炭酸ソーダ $1 \mathrm{~kg}$ は 48 圓位重曹は 140 圓位でする。

摘 要

1. 濇酒然に落泡時以後密閉通氣し發生する炭酸ガスを濕潤した炭酸りーダに接觸させ重曹を作つた。

2. 清酒琴より發生するガスの約 2 割を利用した事になるが，之を本年度の清酒翏の全部に適用したとすれば 主質の重曹約 600 䎲が得られる計算となる。

\section{酒造用乳酸に就

$$
\text { （昭和二十四年四月十三日受理）－， }
$$

鈴木 明治, 伊藤 俊一

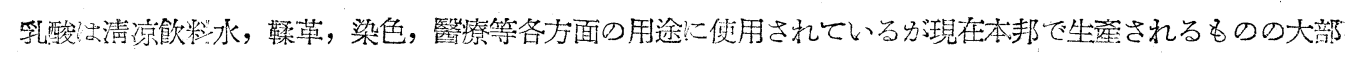

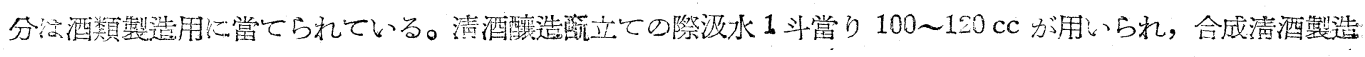
の場合出來上り1石に對し $300 \mathrm{cc}$ 用いられるのが普通であつて, 步の使用量は全體から見れば㥛めて小さい

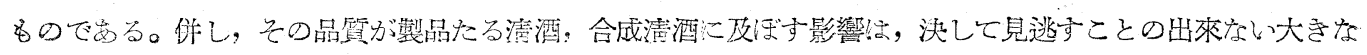
もの苏要る。

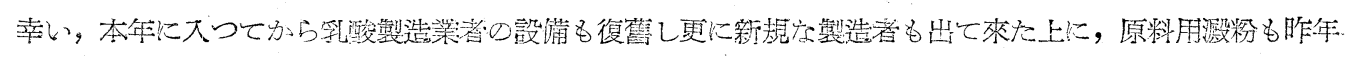

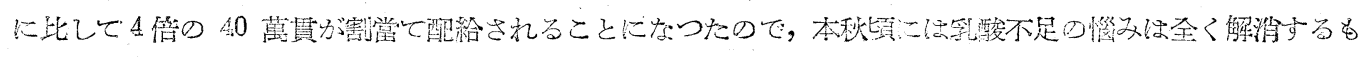

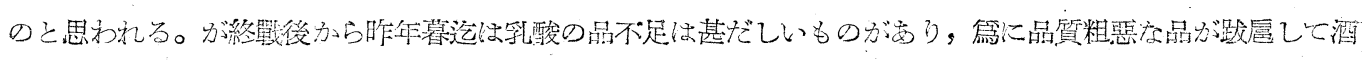

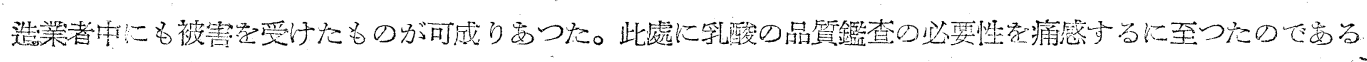

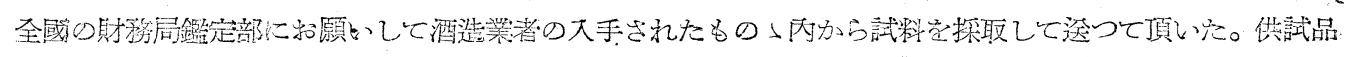
は 32 種に上つたが全くの市販品で岁るので, 之れに上つて全般の品質の倾向学知るととが出來る。

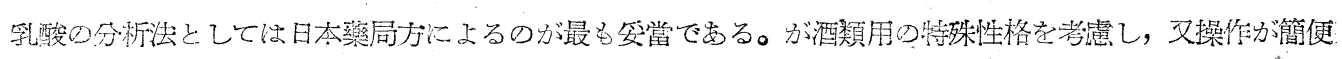

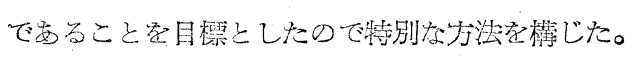

\section{(I) 比重}

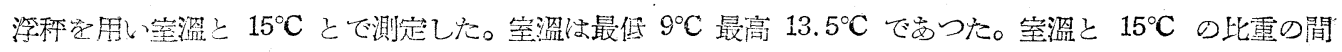
の差は最大 0.010 (室溫 $9^{\circ} \mathrm{C}$ の埸合) 最小 0.001 (堂盕 $13.5^{\circ} \mathrm{C}$ の埸合) であつた。局方では $75 \%$ 乳酸の比 重を 1.210 1.220 と規定している。(15\% $\left.15^{\circ}\right)$ 前述の上うに室溫の埸合と $15^{\circ} / 15^{\circ}$ とでは 0.01 の差がある 